\title{
NEAR-INFRARED SPECTROSCOPY (NIRS) FOR QUALITY ASSURANCE IN BREEDING, CULTIVATION AND MARKETING OF HIGH-OLEIC SUNFLOWERS
}

Received: October 15, 2006 Accepted: December 05, 2006

\section{SUMMARY}

Reliable analytical methods are necessary in order to determine different quality parameters of sunflowers achenes and to realize their optimum utilization in food and non-food industries. For this aim, different near-infrared methods have been developed for ground and intact high-oleic sunflower achenes. These methods determine simultaneously the important quality parameters like oil and protein content and the composition of fatty acids. The methods are adequately exact and more time- and cost-saving than the conventional reference analysis.

In addition to further optimization of the NIRS methods, transfer of the calibration-equations will be worked out. This will lead to a better utility for all those concerned with cultivation, marketing and breeding of sunflowers.

Key words: high oleic sunflower, NIRS, oil, protein, quality assurance

\section{INTRODUCTION}

High oleic sunflower oil is of importance in food and non-food industries. This is due to its special characteristics, for example the high oxidative stability and synthesis of oleic acid, the main fatty acid (>90\% in the oil) in this crop (Käb, 2001). The cultivation of high oleic sunflowers in Germany is presently still a challenge because of fungal diseases (Sclerotinia sclerotiorum, Botrytis cinerea) and agronomical difficulties such as problematic germinating and maturity behavior of the current varieties. In addition to solving the phytopathological problems and the improvement of yield stability of high oleic sunflowers in Germany, it is important to develop a reliable system for quality assurance of this crop. These questions were the topic of a three-year field trial with several high oleic sunflower varieties under different climatic conditions (Dilci et al., 2004).

* Corresponding author: e-mail: bettina.biskupek@bv.fh-hannover.de 
For an efficient utilization of high oleic sunflower oil in food and non food industries, it is necessary to have rapid and reliable analytical methods for determining quality parameters such as oil, moisture and protein contents, composition of fatty acids and the content of free fatty acids (FFA) in the harvested and commercialized high oleic sunflower seeds.

To meet these demands, it will be of great advantage to apply NIRS methods, which are more efficient and more cost effective than most of the wet chemical laboratory methods, which often require the application of hazardous chemicals and are both space and time consuming. A further advantage of NIRS is the simultaneous and simple determination of different parameters (Pérez-Vich et al., 1988; Moschner, 2003). Within the above-mentioned research project, a number of NIRS calibrations for different types of instruments, ground and whole sunflower seeds and several quality traits (e.g., oil, moisture, protein, fatty acid composition and content of free fatty acids) were successfully carried out (Moschner et al., 2005; Moschner et al., 2006).

The focus of the present investigation was to develop near-infrared calibrations for estimating such quality parameters of ground and intact sunflower achenes as oil and protein content and the contents of oleic and linoleic acid and to compare two different NIRS-instruments.

\section{MATERIALS AND METHODS}

Different varieties of high oleic sunflower seeds (mainly Olsavil, PR64H41 and Aurasol) from the harvest years 2002-2005 from two locations in Northern and Southern Germany (Braunschweig and Eckartsweier) were scanned with two different NIR-spectrometers. One was NIRSystems 6500 (FOSS NIRSystems, USA), which works in reflectance mode and scans wavelengths between 400 and $2500 \mathrm{~nm}$ at $2 \mathrm{~nm}$ increments. With this instrument, both ground and intact achenes were measured. The other spectrometer was Infratec 1241 Grain Analyzer (FOSS Tecator, Sweden) which is widely used in the analysis of whole grains, especially rapeseed. In sunflower in contrast, it is only applicable for ground achenes and it scans in transmission mode the wavelengths between 850 and $1050 \mathrm{~nm}$. The samples were scanned as duplicated small ring cups (NIRSystems; ground samples), STM large sample cell (NIRSystems; intact achenes) and $2 \mathrm{~mm}$-Flour-Module-cuvette (Infratec; ground samples).

The important factor in grinding sunflower seeds for NIRS analysis is to obtain a finely ground, pourable and homogenous grist in which the pericarp is also micro-milled. The meal becomes finer as the milling time increases. However, milling the sample for too long causes the destruction of oil bodies and increases the sample temperature; both factors lead to the formation of conglomerates in the meal, which cannot be eliminated by subsequent mixing and have to be avoided. Therefore, it is important to apply a standardized grinding protocol. In this investi- 
gation, $20 \mathrm{~g}$ sunflower seeds per sample were ground in a commercially available coffee mill (Petra Electric M85.00, Peter Hohlfeldt GmbH \& Co. KG, Burgau, Germany) 3 times for 5 seconds each time. The samples were thoroughly mixed during intervals.

For calibration development, the sample parameters were analyzed by reference methods: contents of crude protein (nitrogen determination, DUMAS), oil (NMR) and fatty acids (GC). The calibration equations were performed with WinISI II software (Infrasoft International) using a modified partial least square (MPLS) algorithm. To establish the optimal data pretreatment for each parameter and instrument, the original spectra, $\log (1 / \mathrm{R})$, were used directly or corrected by using $1^{\text {st }}$ and $2^{\text {nd }}$ derivative transformation and standard normal variate and detrend (SNV/detrend) scatter correction. The optimum number of MPLS factors was determined by cross validation. The resulting calibration equations were verified with an independent validation set.

The configuration of the calibration and validation set (range, mean, standard deviation and number of samples) is presented in Table 1.

Table 1: Formation of the calibration and validation set for the parameters protein and oil content (in \% dry matter) and contents of oleic (C18:1) and linoleic (C18:2) acids (in $\%$ of total fatty acids) in high oleic sunflower achenes

\begin{tabular}{lcccccccc}
\hline & \multicolumn{2}{c}{ Protein } & \multicolumn{2}{c}{ Oil } & \multicolumn{2}{c}{ C18:1 } & \multicolumn{2}{c}{ C18:2 } \\
\cline { 2 - 9 } & Cal. & Val. & Cal. & Val. & Cal. & Val. & Cal. & Val. \\
\hline Min & 10,7 & 10,7 & 42,4 & 44,4 & 80,2 & 81,7 & 1,8 & 1,8 \\
Max & 23,8 & 23,0 & 57,7 & 56,5 & 93,2 & 93,0 & 11,7 & 10,6 \\
Mean & 15,3 & 15,3 & 50,9 & 50,9 & 89,2 & 89,3 & 3,9 & 3,9 \\
SD & 2,0 & 2,0 & 2,4 & 2,7 & 2,2 & 2,2 & 1,5 & 1,6 \\
$\mathrm{n}$ & 707 & 233 & 1062 & 243 & 731 & 243 & 731 & 243 \\
\hline
\end{tabular}

The accuracy of the validated calibration was described by SEP (standard error of prediction), RSQ (multiple coefficient of determination in validation) and RPD, which were calculated as ratio of standard error to the standard deviation of the validation samples (SDval/SEP, respectively).

\section{RESULTS AND DISCUSSION}

The statistics of the developed and validated calibration for the estimation of different parameters like protein and oil content as well as content of oleic and linoleic acid in ground and intact high oleic sunflower achenes are summarized in Table 2 .

The highest prediction accuracy in this investigation was achieved with the NIRSystems and the use of ground achenes. This method had the lowest standard error of prediction (SEP) accompanied by high multiple coefficients of determination (RSQ). Moreover, the highest RPD-values were obtained by using the NIRSys- 
tems and ground achenes. These RPD-values (ideally 5 or more, at least 3), indicate efficient NIR predictions (Williams, 2001).

Table 2: Validation statistics for the parameters protein and oil content (in \% dry matter) and contents of oleic (C18:1) and linoleic (C18:2) acids (in \% of total fatty acids) in high oleic sunflower achenes

\begin{tabular}{lccccccccc}
\hline & \multicolumn{3}{c}{$\begin{array}{c}\text { NIRSystems } \\
\text { Ground achenes }\end{array}$} & \multicolumn{3}{c}{$\begin{array}{c}\text { NIRSystems } \\
\text { Intact achenes }\end{array}$} & \multicolumn{3}{c}{$\begin{array}{c}\text { Infratec } \\
\text { Ground achenes }\end{array}$} \\
\cline { 2 - 10 } & SEP & RSQ & RPD & SEP & RSQ & RPD & SEP & RSQ & RPD \\
\hline Protein & 0,58 & 0,92 & 3,4 & 0,89 & 0,80 & 2,2 & 0,82 & 0,84 & 2,4 \\
Oil & 0,84 & 0,90 & 3,2 & 1,03 & 0,83 & 2,4 & 1,21 & 0,78 & 2,1 \\
C18:1 & 0,42 & 0,96 & 5,2 & 1,04 & 0,76 & 2,0 & 1,60 & 0,42 & 1,3 \\
C18:2 & 0,24 & 0,98 & 6,8 & 0,87 & 0,66 & 1,7 & 1,13 & 0,39 & 1,3 \\
\hline
\end{tabular}

Obviously the estimation of quality parameters of intact achenes is not as exact as the results for ground achenes; as shown by high SEPs and low multiple coefficients of determination and RPD values, especially for the prediction of the two fatty acids. The accuracy of estimation is sufficient for many applications and it offers additional advantages: it provides a substantial reduction of work through omission of grinding and cleaning the cuvettes, it enables breeders to consider several parameters while bringing selection decisions and to use the same material after the nondestructive measurement.

The lower prediction accuracy in intact achenes instead of ground ones when scanned with the NIRSystems may be due to the lack of spectral information in the original spectra. As shown in Figure 1, these raw data demonstrate much lower absorption for the spectral region of the intact achenes, e.g., for the main absorption regions of the fatty acids (approx. 1700 and $2300 \mathrm{~nm}$ ), which finally leads to less information for those wavelengths.
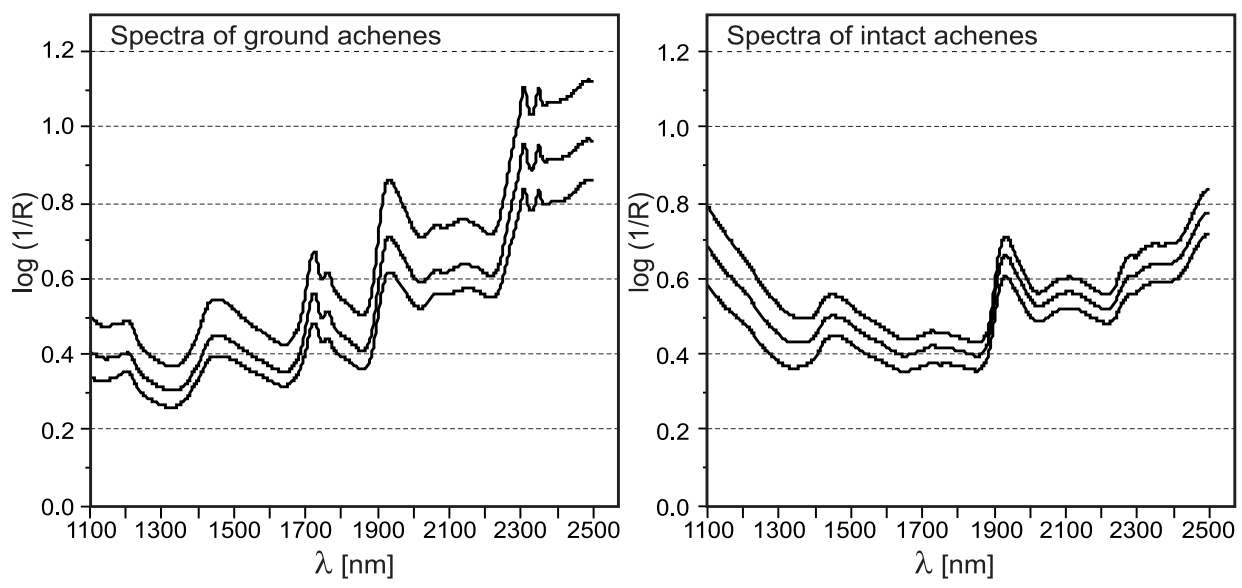

Figure 1: Near-infrared spectra of three samples scanned by NIRSytems 6500 in small ring cup as ground sunflower achenes and in STM large sample cell as intact achenes, respectively 
The results achieved for the Infratec indicate that the use of this spectrometer is appropriate for the parameters protein and oil content, whereas the prediction accuracy for the fatty acids is not satisfying. This is probably due to the fact that the main absorption bands of the fatty acids are located in the above-mentioned spectral regions around 1700 and $2300 \mathrm{~nm}$, respectively, which both lie beyond the wavelength range of the Infratec.
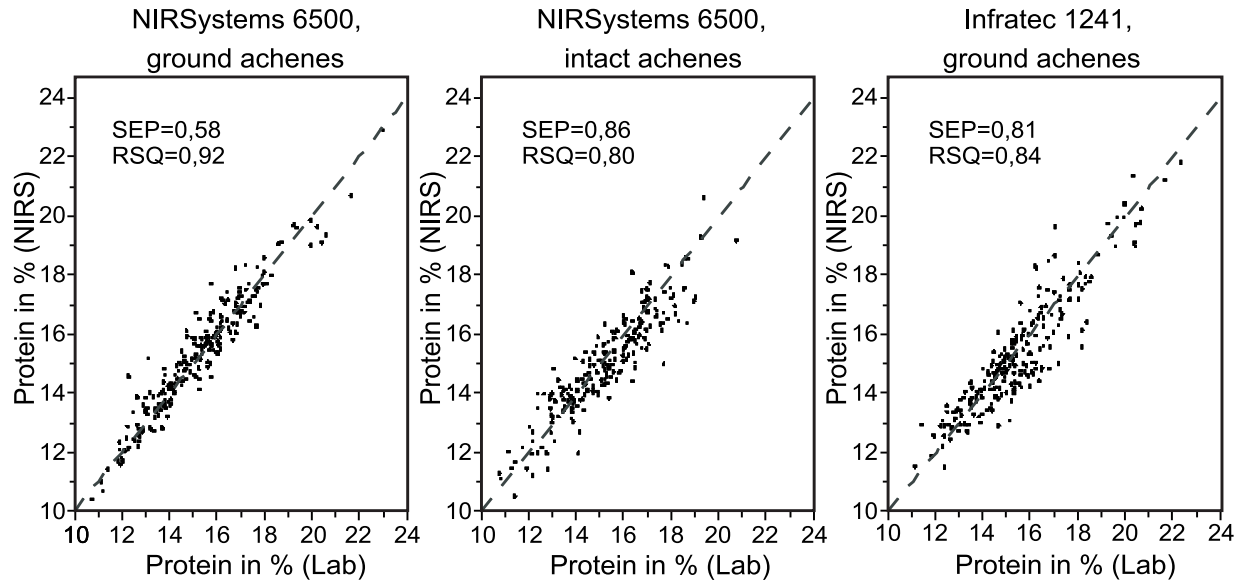

Figure 2: Validation plots for protein content (reference values vs. predicted values)

The described differences between these three methods can be illustrated by comparing the validation plots for protein content (Figure 2) and for the content of oleic acid (Figure 3). In the diagrams, the actual contents of the validation samples on the $\mathrm{x}$-axis are plotted against the predicted contents on the ordinate.
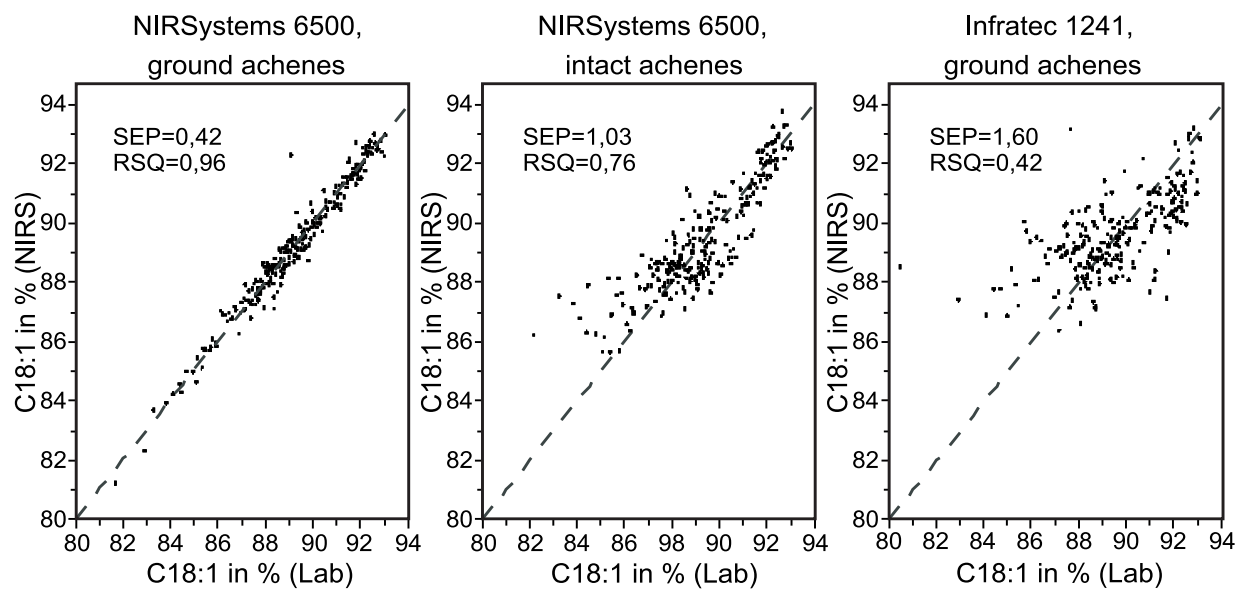

Figure 3: Validation plots for oleic acid content (reference values vs. predicted values)

The dashed line represents the bisecting line. In the case of the estimation of the protein contents of sunflower achenes (Figure 2), the plots demonstrate that all 
of the three investigated methods lead to acceptable and comparable results. But for the prediction of oleic acid contents (Figure 3) we have to draw a different kind of conclusion. For this constituent the validation plots clearly indicate the existence of differences between the methods: while the prediction of ground achenes with the NIRSystems shows a high accuracy, the use of intact achenes and especially the application of the Infratec lead to partially significant deviations between the predicted and measured values.

\section{CONCLUSIONS}

In the present study the obtained results demonstrate convincingly the suitability of the NIRS methods for the estimation of different quality parameters of ground and intact sunflower achenes. Further development of the methods is the aim of further investigations. An extension of the present database (e.g. with fresh-harvested samples), and recalibration will lead to more robust calibrations.

For an efficient use of the "intact achenes" method in practical breeding the sample quantity (presently approx. $150 \mathrm{~g}$ ) has to be reduced. This can be obtained by the use of smaller cuvettes in combination with the transfer of the current NIRSmethod by algorithms like PDS (piecewise direct standardization) in order to nevertheless achieve good predictions. The PDS algorithm has been implemented in commercial NIRS-Software recently and is proved to be very efficient for the transfer of spectral data to new scanning methods, like the application of other cuvettes, or the transfer of the spectra to other instruments (Fearn, 2001). With such a change of the „intact achenes” method from the currently used large sample cell to a small ring cup, it should be possible to reduce the required amount of sunflower achenes to approximately $3 \mathrm{~g}$ (see Figure 4). However, for large achenes, it would be necessary to use a slightly bigger cuvette with a charge of approximately $20 \mathrm{~g}$. Both cases provide substantial progress to practical sunflower breeding.

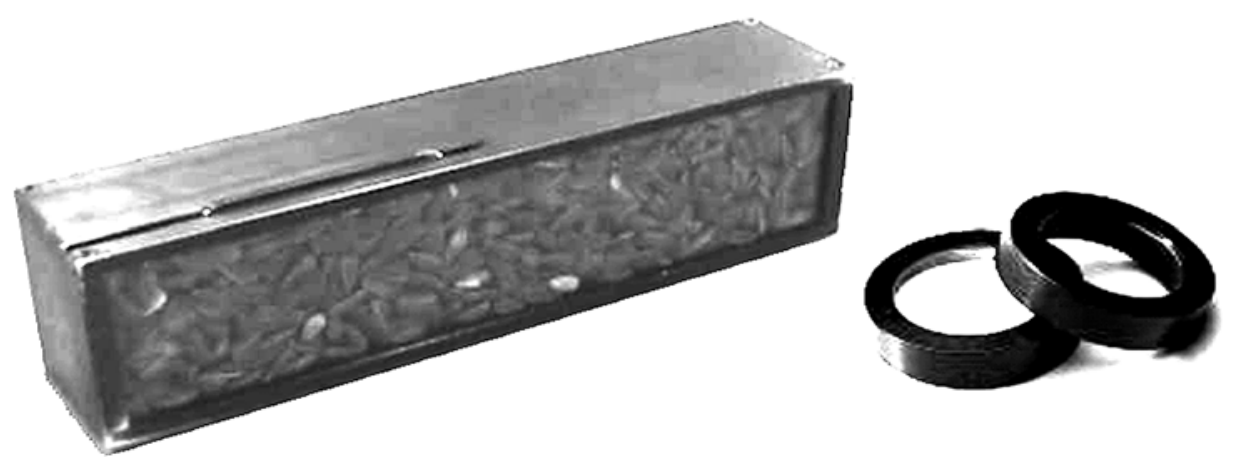

Figure 4: Cuvette of the type "STM large sample cell" fill with approx. $150 \mathrm{~g}$ intact sunflower achenes and cuvettes of the type "small ring cup" with a filling quantity of approximately $3 \mathrm{~g}$ intact sample material 
The results of this investigation show that it is possible to use the reliable and rapid NIRS methods for quality assurance in breeding, cultivation and marketing of high-oleic sunflowers. The rapid and simultaneous determination of important quality traits with the developed NIRS methods offers a considerable advantage in the course of producing, trading and processing of this important oilseed.

\section{ACKNOWLEDGEMENTS}

Sincere thanks to Agravis Raiffeisen AG, Hannover, Germany, for the financial support of the previous investigations as well as to the Agency of Renewable Resources (FNR), Gülzow, Germany, for financing of the current project. Special thanks go to G. Rühl and C. Paul from the Federal Agricultural Research Centre (FAL), Braunschweig, Germany, as well as V. Hahn from the University of Hohenheim for good cooperation.

\section{REFERENCES}

Käb, H., 2001. High-Oleic Öl: Industrierohstoff der Zukunft. In: Agency of Renewable Resources (Eds.), Nachwachsende Rohstoffe für die Chemie - 7. Symposium 2001, Landwirtschaftsverlag $\mathrm{GmbH}$, pp. 99-1 15.

Dilci, B., Rühl, G., Hahn, V., Biskupek-Korell, B. and Moschner, C.R., 2004. Ertrags- und Qualitätssicherung von High-Oleic-(HO) Sonnenblumen. In: Kauter, D., Kämpf, A., Claupein, W. and Diepenbrock, W. (Eds.), Mitteilungen der Gesellschaft für Pflanzenbauwissenschaften- Band 16, Verlag Günter Heimbach, pp. 203-204.

Pérez-Vich, B., Velasco, L. and Fernández-Martinéz, J.M., 1988. Determination of Seed Oil Content and Fatty Acid Composition in Sunflower Through the Analysis of Intact Seeds, Husked Seeds, Meals and Oil by Near-Infrared Reflectance Spectroscopy. Journal of the American Oil Chemists' Society 75: 547-555.

Moschner, C.R., 2003. Abschätzung des Gehaltes wertgebender Inhaltsstoffe von Sonnenblumensaat mittels Nahinfrarotspektroskopie. Diploma thesis, University of Applied Sciences and Arts Hannover.

Moschner, C.R. and Biskupek-Korell, B., 2005. Qualitätssicherung bei Anbau und Vermarktung von high-oleic (HO)-Sonnenblumen durch Einsatz nahinfrarotspektroskopischer Methoden. In: Kämpf, A., Claupein, W., Graeff, S. and Diepenbrock, W. (Eds.), Mitteilungen der Gesellschaft für Pflanzenbauwissenschaften- Band 17, Verlag Günter Heimbach, pp. 211-212.

Moschner, C.R. and Biskupek-Korell, B., 2006. Estimating the Content of Free Fatty Acids (FFA) in High Oleic Sunflower Seeds by Near-Infrared Spectroscopy (NIRS). European Journal of Lipid Science and Technology 108: 606-613.

Williams, P.C., 2001. Implementation of Near-Infrared Technology. In: Williams, P.C and Norris, K. (Eds.), Near-Infrared Technology in the Agricultural and Food Industries $-2^{\text {nd }}$ edition, American Association of Cereal Chemists, pp. 145-170.

Fearn, T., 2001. Standardisation and calibration transfer for near infrared instruments: a review. Journal of Near Infrared Spectroscopy 9: 229-244. 


\title{
UTILIZACIÓN DE ESPECTROSCOPIA INFRARROJA NIRS PARA PRUEBA DE CALIDAD DE SELECCIÓN, CULTIVO Y COMERCIALIZACIÓN (MERCADEO) DE GIRASOL ALTO OLEICO
}

\author{
RESUMEN
}

Los métodos analíticos fiables son necesarios en la determinación de los parámetros cualitativos de la semilla de girasol, tanto como en determinación de utilización óptima de esa semilla en la producción de alimentos y otros productos no alimenticios. Con este objetivo se han desarrollado diferentes métodos infrarrojos de NIRS para el análisis de la semilla molida y entera del girasol alto oleico. Estos métodos al mismo tiempo determinan importantes parámetros de calidad, como son el contenido de aceite y de proteínas, y el contenido de ácidos grasos. La exactitud de los métodos es satisfactoria, tanto como su economicidad en cuanto a los gastos y ahorro del tiempo en relación con los métodos de referencia convencionales.

Junto con el avance de optimización del método NIRS, se trabajará en la implementación de las ecuaciones de calibración. Con esto, ellos van a hacerse muy útiles para todos los que se dedican al cultivo, venta y selección de girasol.

\section{UTILISATION DE LA SPECTROSCOPIE INFRAROUGE (NIRS) DANS LA CONFIRMATION DE LA QUALITÉ DE LA SÉLECTION, DE LA CULTURE ET DU PLACEMENT DU TOURNESOL À HAUTE TENEUR OLÉIQUE}

\author{
RÉSUMÉ
}

Des méthodes d'analyse fiables sont nécessaires dans la détermination de différents paramètres de qualité des akènes de tournesol et dans la réalisation de leur utilisation optimale dans les industries alimentaires et non alimentaires. Dans ce but, différentes méthodes infrarouges ont été développées pour l'analyse des akènes de tournesol à haute teneur oléique moulus ou entiers. Ces méthodes déterminent en même temps les paramètres de qualité importants comme le contenu d'huile et de protéines et la composition des acides gras. Les méthodes sont suffisamment exactes et plus économiques relativement au temps et au coû HYBHYHH que l'analyse de référence conventionnelle.

En plus d'une optimisation ultérieure des méthodes NIRS, l'implémentation des équations de calibration sera effectuée. Cela sera très profitable à tous ceux qui s'occupent de culture, de vente et de sélection du tournesol.

Presented at:

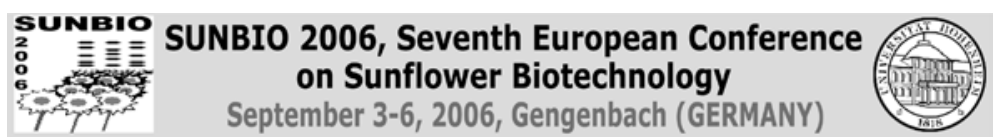

